\title{
Komunikasi Interpersonal Kepala Keluarga Berbasis Capacity Building dalam Mencegah Kenakalan Remaja
}

\section{Interpersonal Communication Head of the Family Based Capacity Building in Preventing Juvenile Delinquency}

\author{
Zuhriah* \\ Program Studi Ilmu Komunikasi, Fakultas Ilmu Sosial, \\ Universitas Islam Negeri Sumatera Utara, Indonesia
}

Diterima: Agustus 2019; Disetujui: Desember 2019; Dipublish: Desember 2019

*Coresponding Email: zuriah@uinsu.ac.id

\begin{abstract}
Abstrak
Fenomena kenakalan remaja terjadi hampir di setiap wilayah di Indonesia. Arus globalisasi menjadi pendorong terjadinya kenakalan remaja saat ini. Kondisi tersebut terlihat dari perilaku remaja yang kerap menunjukkan sikap apatis dan egois dan lingkungan sekitarnya. Di luar rumah remaja juga kerap melakukan tindakan-tindakan diluar batas seperti membolos sekolah, minum-minuman keras, tawuran dan berjudi. Perilaku tersebut mencerminkan kurangnya komunikasi interpersonal yang dibangun oleh orangtua dalam membina anaknya dan tidak ada strategi khusus didalam mencegah perilaku tersebut. Tujuan penulisan adalah untuk menggambarkan bagaimana komunikasi interpersonal yang dterpakan oleh kepala keluarga berbasis capacity building. Capacity building adalah proses di mana individu dan organisasi memperoleh, meningkatkan, dan mempertahankan keterampilan, pengetahuan, peralatan, peralatan, dan sumber daya lainnya yang diperlukan untuk melakukan pekerjaan mereka secara kompeten. Ini memungkinkan individu (kepala keluarga) untuk hadir membangun komunikasi interpersonal pada kapasitas yang lebih besar dalam mengantisipasi keterlibatan anaknya dalam kenalakalan remaja. Dalam melakukan capacity building individu, diukur melalui yaitu pengambilan keputusan, komunikasi keluarga, pengawasan.
\end{abstract}

Kata Kunci; Komunikasi, Interpersional, Kepala Keluarga, Capacity Building, Remaja

\begin{abstract}
The phenomenon of juvenile delinquency occurs in almost every region in Indonesia. The current of globalization is the driving force for juvenile delinquency today. This condition is seen from the behavior of adolescents who often show apathetic and selfish attitudes and the surrounding environment. Outside the home teenagers also often take actions outside the bounds such as ditching school, drinking, brawl and gambling. The behavior reflects the lack of interpersonal communication that is built by parents in fostering their children and there is no specific strategy in preventing the behavior. The purpose of writing is to describe how interpersonal communication is applied by the head of the family based on capacity building. Capacity building is the process by which individuals and organizations acquire, improve and maintain the skills, knowledge, tools, equipment, and other resources needed to carry out their work competently. This allows the individual (head of the family) to attend to build interpersonal communication in a greater capacity in anticipating the involvement of their children in juvenile delinquency. In carrying out individual capacity building, measured through the concept of Gross namely decision making, communication, control.
\end{abstract}

Keywords: Communication, Interpersonal, Family Head, Capacity Building, Youth

How to Cite: Zuriah. (2019). Komunikasi Interpersonal Kepala Keluarga Berbasis Capacity Building Dalam Mencegah Kenakalan Remaja. Journal of Education, Humaniora and Social Sciences (JEHSS). 2 (2): 188-195. 


\section{PENDAHULUAN}

Kenakalan remaja adalah partisipasi oleh anak kecil, biasanya antara usia 10 dan 17, dalam perilaku atau kegiatan ilegal. Kenakalan remaja merujuk pada anak-anak yang menunjukkan perilaku terus-menerus kenakalan atau ketidakpatuhan, sehingga dianggap di luar kendali orangtua, menjadi subyek tindakan hukum oleh sistem pengadilan. Kenakalan remaja juga dikenal sebagai "pelanggaran remaja," dan masingmasing negara memiliki sistem hukum yang terpisah untuk menangani remaja yang melanggar hukum. (Diana, 2017).

Statistik kenakalan remaja banyak organisasi, termasuk OJJDP (The Office of uneville Justice and Delinquency Prevention (https://legaldictionary.net/juveniledelinquency), mempelajari kenakalan remaja, dan melaporkan data yang terkompilasi untuk mempelajari apa yang berkontribusi pada masalah kenakalan remaja. Beberapa statistik kenakalan remaja terbaru meliputi: 1) Pada 2012, polisi menangkap 182 pelaku kekerasan remaja untuk setiap 100.000 remaja; 2) Usia puncak jatuh antara 15 dan 19 tahun; 3) 52\% hingga 57\% dari pelaku remaja terus menyinggung ke pertengahan 20 -an mereka; 4) Pada usia 30, hanya $16 \%$ sampai 19\% dari kenakalan remaja terus berlangsung; 5) Usia rata-rata keterlibatan geng adalah 16 tahun; 6) Usia rata-rata penggunaan narkoba adalah 16 hingga 17 tahun

Namun, ada tanda-tanda tertentu bahwa seorang anak mungkin menuju ke arah yang buruk. Prediktor kenakalan remaja dapat muncul sedini mungkin dan sering termasuk dalam pelanggaran kronis terhadap aturan. Studi telah menemukan bahwa sejumlah keadaan kehidupan merupakan faktor risiko bagi seorang anak untuk menjadi kenakalan remaja.

Sementara ini banyak dan beragam, faktor risiko paling umum untuk kenakalan remaja pertama pola asuh otoriter ditandai dengan penggunaan metode disiplin yang keras, dan penolakan untuk membenarkan tindakan disipliner. Kedua, Peer Association biasanya dihasilkan dari meninggalkan remaja tanpa pengawasan, mendorong anak untuk terlibat dalam perilaku buruk ketika bertindak dengan kelompok teman sebayanya.

Ketiga, pola asuh permisif ditandai dengan kurangnya konsekuensi untuk perilaku buruk, pola asuh permisif dapat dibagi menjadi dua subkategori: (1) pola asuh yang lalai, yang merupakan kurangnya pemantauan kegiatan anak, dan (2) pola asuh yang 
memanjakan, yang merupakan enablement dari perilaku buruk. Menyikapi kenakalan remaja orangtua harus mampu menerapkan strategi khusus dan memposisikan diri sebagai individu yang bertanggungjawab terhadap muncul sikap dan perilaku kenakalan remaja. Upaya yang dilakukan dengan komunikasi interpersonal berbasis capacity buiding yaitu sebuah tindakan yang mengedepankan interaksi komunikasi dengan anak remaja, pengambilan keputusan, pengontrolan terhadap kegiatan keseharian anak remaja (Lundman, 2001).

Pencegahan kenakalan remaja harus dimulai dari lingkungan keluarga (Suharyanto, 2015). Pencegahan tersebut dapat dilakukan dengan kerjasama dengan sejumlah lembaga pemerintah dan swasta, dan mencakup layanan seperti perawatan penyalahgunaan zat aditif, konseling keluarga, konseling Perorangan, pendidikan parenting dan layanan keluarga berencana (Siregar, 2015). Di sisi lain ketersediaan pendidikan, dan dorongan anak untuk mendapatkan pendidikan, memainkan peran besar dalam pencegahan kenakalan remaja. Ini karena pendidikan mendorong kohesi sosial, dan membantu anak remaja mempraktikkan pengendalian diri. (B.Parks, , 2013).

\section{PEMBAHASAN}

\section{Pengambilan Keputusan}

Mengingat perkembangan kenakalan remaja selama beberapa dekade terakhir telah menunjukkan bahwa kondisi individu, sosial, dan masyarakat serta interaksi mereka mempengaruhi perilaku diperlukan upaya capacity building orangtua dalam pengambilan keputusan agar terhindar dari kenakalan remaja. Pengambilan keputusan adalah suatu pendekatan yang sistematis terhadap hakikat alternatif yang dihadapi dan mengambil tindakan yang menurut perhitungan merupakan tindakan yang paling tepat.

Pengambilan keputusan merupakan proses yang digunakan untuk memilih suatu tindakan sebagai cara pemecahan masalah perilaku anak remaja. Ada kesepakatan umum bahwa perilaku, termasuk perilaku antisosial dan nakal, adalah hasil dari interaksi yang kompleks antara faktor-faktor biologis dan genetik individu dan faktor lingkungan, dimulai selama perkembangan janin dan berlanjut sepanjang (Goode, 2005). Jelas, gen mempengaruhi perkembangan biologis, tetapi tidak ada perkembangan biologis tanpa input lingkungan. Dengan demikian, biologi dan lingkungan mempengaruhi perilaku. 
Meskipun faktor-faktor risiko tersebut dapat membantu mengidentifikasi anakanak mana yang paling membutuhkan intervensi pencegahan, juga dapat mengidentifikasi anak-anak tertentu yang akan menjadi pelanggar serius atau kronis. Kepala keluarga dalam hal ini bermain peran dalam melakukan pencegahan terhadap dinamika individu yang terjadi pada anak remaja. Sikap yang diambil harus mencerminkan ketegasan didalam bersikap seperti dalam pengambilan keputusan religiusitas yang dapat membawa anak remaja untuk menghayati dan menginternalisasikan ajaran agamanya sehingga cara ini dapat berpengaruh dalam semua tindakan dan pandangan hidupnya. Kepala keluarga menjadi salah satu faktor pembentuk sikap anak remaja, pemahaman yang baik oleh anak remaja dari orangtua dapat memberikan garis pemisah antara sesuatu yang boleh dan dilarang.

Disisi lain pemilihan pendidikan juga menjadi hal yang paing penting di dalam menentukan pembentukan sikap dan perilaku anak remaja. Terutama dalam memilih jenis sekolah anak. Dikarenakan selain lingkungan keluarga, faktor pendidikan juga sangat berpotensi membangun karakter seorang anak. Berbagai pengetahuan yang mereka dapatkan disekolah diterapkan dalam kehidupan sehari-hari. Konsep moral dan ajaran agama sangat menentukan sistem kepercayaan serta memiliki peranan penting dalam menentukan sikap individu terhadap sesuatu hal yang akan dilakukannya kedepan. Dalam konteks komunikasi interpersonal kedekatan antara orangtua dengan remaja berkontribusi terhadap perilaku kenakalan remaja yang menunjukan bahwa kekuatan hubungan tersebut dapat mengurangi kemungkinan seorang remaja terlibat kedalam kenakalan (Platt, 2001).

\section{Komunikasi Keluarga}

Gaya pengasuhan dan komunikasi keluarga memiliki dampak pada kenakalan remaja. Komunikasi keluarga, sebagaimana didefinisikan oleh (Mwangangi, 2019) memandang keluarga diciptakan dan dipertahankan lebih banyak melalui komunikasi dari pada melalui struktur (misalnya: cara keluarga berkomunikasi mendefinisikan mereka sebagai keluarga yang melebihi apapun. Lebih lanjut juga menyatakan kenakalan remaja terjadi karena masih didapati keluarga yang berfikir ayah sebagai pencari nafkah dan ibu rumah tangga tugasanya mengurusi sekolah anak-anak. 
Komunikasi adalah pusat kehidupan keluarga sampai saat ini. Namun, kebanyakan fungsi tradisional keluarga telah didelegasikan ke agensi sosial lainnya (misalnya perawatan lansia dan pendidikan anak-anak. Meskipun asuhan dalam keluarga tetap konstan. Fungsi pengasuhan ini berlangsung terutama melalui pertukaran verbal dan nonverbal pesan ( http://www.comm.umm.edu/ akoerner/RFCP-quesionnaire. pdf. ). Komunikasi antara anak-anak dan orang tua mereka dapat menyajikan beberapa masalah khusus untuk keluarga (Suharyanto, et.al., 2017). Komunikasi disertai dengan dukungan dan pengasuhan dalam keluarga juga bisa menjadi sangat tegang ketika anakanak mencapai usia remaja.

Menurut Masselam et al. (1990), komunikasi berhubungan dengan iklim interaksi interpersonal yang efektif, dan itu adalah ketika keluarga memasuki tahap kehidupan remaja. Selama ini tahap kehidupan remaja cenderung diminimalkan. Pentingnya partisipasi mereka dalam acara dengan mereka keluarga, seperti tamasya keluarga atau pertemuan, adalah bentuk komunikasi interpersonal yang dapat dibangun.

Ada beberapa penelitian yang berusaha menghubungkan antara komunikasi dalam keluarga dan tingkah laku nakal. Menurut penelitian yang dilakukan oleh Novy, Gaa, Frankiewicz, Liberman, dan Amerikaner (1992) dalam (White, 1997), keluarga dengan kenakalan remaja cenderung ditandai dengan terlibatnya keluarga dalam ketegangan komunikasi. Terjadinya komunikasi yang negative sehingga menjadi sangat tidak terstruktur dan semrawut.

Selanjutnya hasil penelitian tersebut menjelaskan bahwa di bidang komunikasi orang tua-anak menunjukkan tingkat komunikasi yang tinggi membantu anak-anak untuk mencapai keberhasilan akademis yang tinggi dan bahwa mereka akan jauh lebih sedikit putus sekolah atau bersekolah di sekolah alternatif. Ini berarti sebagai orang tua harus tetap hadir di kehidupan anak-anak mereka melalui komunikasi yang positif. Anak remaja memiliki peluang lebih besar untuk sukses jika didukung komunikasi yang lebih baik dengan orangtua.

Konsep diri dan evaluasi komunikasi orang tua dan perkawinan menunjukkan bahwa jika anak-anak menganggap pernikahan orang tua mereka sebagai pernikahan yang baik dengan banyak komunikasi positif, maka siswa mendapat konsep diri yang positif. Komunikasi yang terbuka membantu menghasilkan konsep diri remaja yang positif. Komunikasi adalah kunci yang memungkinkan keluarga untuk bergerak menuju 
dan mempertahankan tingkat keseimbangan kohesi keluarga dan kemampuan beradaptasi Tanpa komunikasi positif, remaja lebih rentan untuk terlibat dalam tindakan nakal melalui pengaruh rekan nakal. Remaja yang mengalami suportif, terbuka, mengalir bebas, komunikasi nonproblematic antara anggota keluarga akan mempertahankan status mereka di dalam keluarga (misalnya mereka tidak ingin membahayakan posisi mereka dalam keluarga dengan menempatkan diri dalam masalah dengan rekan yang nakal.

\section{Pengawasan Keluarga}

Pengawasan keluarga berfungsi sebagai sosialisasi bagi setiap remaja yang tumbuh menjadi dewasa. Maka dari itu, diperlukan suatu sistem nilai sebagai semacam pedoman untuk mengarahkan aktivitasnya dalam masyarakat dan berfungsi sebagai tujuan akhir pengembangan kepribadiannya. Kedua orangtua mewariskan kepada anak-anak mereka dengan cara informal dan tidak disadari tentang sistem nilai masyarakat.

Nilai-nilai yang sudah diwariskan kedua orang tua misalnya berupa pengaturan hubungan antara anggota keluarga. Lebih lanjut, nilai-nilai masyarakat yang mereka lakukan penting sekali untuk mempertahankan masyarakat itu sendiri pada generasi yang akan datang. Fungsi pengawasan dalam keluarga titik beratnya adalah dalam mempertahankan dan melestarikan nilai-nilai masyarakat melalui peran sosial anggota keluarga, berupa ketiaksediaan anggota keluarga untuk bergaul dengan orang yang mereka anggap telah melanggar norma-norma masyarakat.

Peran Keluarga dalam mengontrol kenakalan remaja melalui peningkatan perkembangan anak. Pengasuhan anak yang tepat adalah tanggung jawab utama orang tua, karena nilai-nilai yang diberikan kepada anak-anak dan jenis pelatihan yang mereka terima dari orang tua dan mereka sangat menentukan gaya hidup masa depan mereka. Orang tua membantu anak-anak mereka membangun sikap perilaku tertentu, dan begitu didirikan sikap ini sulit untuk diubah atau ditekan. Orang tua yang menanamkan sikap dan perilaku antisosial pada anak-anak mereka mendorong sikap seperti itu untuk bertahan hingga dewasa.

Perkembangan anak remaja memiliki aspek emosional, intelektual, sosial dan fisik, dengan keluarga menjadi landasan di mana perkembangan ini terjadi. Pengawaaan 
keluarga memainkan peran penting dalam membentuk anak dengan memberikan keamanan dan mengembangkan nilai-nilai dan keterampilan mereka.

Anak-anak remaja bergantung pada keluarga untuk kebutuhan dasar mereka, seperti pakaian, tempat tinggal dan makanan, dengan keluarga mereka memberikan rasa keamanan fisik utama mereka. Mereka juga mendapatkan keamanan emosional dari keluarga yang tidak dapat menemukan tempat lain, memungkinkan anak-anak tumbuh dalam kepercayaan diri dan dapat mengekspresikan diri mereka sepenuhnya. Memberi anak-anak rutin dirumah yang stabil juga memungkinkan mereka merasa aman, karena mereka tahu mereka akan makan, minum, mandi, dan tidur pada waktu-waktu tertentu tanpa terganggu. Pengawasan terhadap bagi anak remaja adalah resep bagi mereka untuk mengembangkan keterampilan dan bakat mereka, tumbuh secara fisik, dan berkembang secara kognitif dan emosional. Keamanan juga penting dalam membangun kepercayaan antara anak-anak dan anggota keluarga. Ketika anak-anak tahu bahwa mereka dapat mempercayai orang-orang di sekitar mereka, mereka merasa lebih nyaman dan aman.

\section{SIMPULAN}

Dari penjelasan hasil penelitian dan pembahasan yang telah diuraikan diatas maka yang menjadi kesimpulan dalam penelitian ini adalah bahwa. Ini memungkinkan individu (kepala keluarga) untuk hadir membangun komunikasi interpersonal pada kapasitas yang lebih besar dalam mengantisipasi keterlibatan anaknya dalam kenalakalan remaja. Dalam melakukan capacity building individu, diukur melalui yaitu pengambilan keputusan, komunikasi, pengawasan.

\section{DAFTAR PUSTAKA}

B. Parks, A. (, 2013). The Effects of Family Structure on Juvenile Delinquency . East Tennese: School of Graduate Studies East Tennese State University.

Diana, A.D. (2017). Kecenderungan Kenakalan Remaja Ditinjau Dari Kekuatan Karakter Dan Persepsi Komunikasi Empatik Orangtua . Jurnal Psikologi Integratif , Vol. 5 No. 1, 47-68.

Goode, B.A. (, 2005). Behavioral intention formation in knowledge sharing : Examining the roles of extrinsic motivators, social-psychological forces, and organizational climate. MIS Quarterly, 29 (1), 87-111.

http://www.comm.umm.edu/ akoerner/RFCP-quesionnaire. pdf. .

https://legaldictionary.net/juvenile-delinquency),. (n.d.).

Lundman, R.J. (2001). Prevention and Control of Juvenille Delinquency. Texas: Oxpord University.

Mwangangi, R.K. (2019). The Role of Family in Dealing with Juvenile Delinquency . Open Journal of Social Sciences, Vol. 7, 52-63.

Platt, A.M. (2001). Saving and Controlling Delinquent Youth. JSTOR, 24.

1. $\mathrm{A}$ http://mahesainstitute.web.id/ojs2/index.php/jehss 
Siregar, N.S.S., (2015). Latar Belakang Tindakan Kenakalan Anak pada Usia 13 sampai 17 Tahun, JPPUMA: Jurnal Ilmu Pemerintahan dan Sosial Politik UMA (Journal of Governance and Political UMA), 3 (1): 88-103.

Suharyanto, A. (2015). Pendidikan dan Proses Pembudayaan dalam Keluarga, JUPIIS: Jurnal Pendidikan Ilmu-Ilmu Sosial, 7 (2) (2015): 162-165.

Suharyanto, A. Matondang, A. Walhidayat, T. (2017). The Interpersonal Communication of the Chinese Ethnic Families in Cheng Beng Ceremony in Medan, Indonesia. IOSR Journal Of Humanities And Social Science (IOSR-JHSS), 22(12)Ver.4:38-44

White, M. (, 1997). Parenting Styles And Family Communication . Medan: Graduate Student USU Family and Human Development Department . 